\title{
Nerve Stretch Injury Induced Pain Pattern and Changes in Sensory Ganglia in a Clinically Relevant Model of Limb-Lengthening in Rabbits
}

\author{
K. PAP ${ }^{1}$, Á. BERTA ${ }^{1}$, G. SZŐKE ${ }^{2}$, M. DUNAY ${ }^{3}$, T. NÉMETH ${ }^{3}$, K. HORNOK $^{4}$, \\ L. MAROSFÖI ${ }^{5}$, M. RÉTHELYI ${ }^{5}$, M. KOZSUREK ${ }^{5}$, Z. PUSKÁR $^{5}$
}

${ }^{1}$ Department of Traumatology, Semmelweis University \& Department of Orthopedics and Traumatology, Uzsoki Hospital, Budapest, Hungary, ${ }^{2}$ Department of Orthopedics, Semmelweis University, Budapest, Hungary, ${ }^{3}$ Department and Clinic of Surgery and Ophthalmology, Faculty of Veterinary Science, Szent István University, Budapest, Hungary, ${ }^{4}$ Division of Pharmacology and Drug Safety, Richter Gedeon Plc, Budapest, Hungary, ${ }^{5}$ Szentágothai János Laboratory, Department of Anatomy, Histology and Embryology, Semmelweis University, Budapest, Hungary

Received February 13, 2014

Accepted July 21, 2014

On-line December 3, 2014

\section{Summary}

We used a model of tibial lengthening in rabbits to study the postoperative pain pattern during limb-lengthening and morphological changes in the dorsal root ganglia (DRG), including alteration of substance $\mathrm{P}$ (SP) expression. Four groups of animals (naïve; OG: osteotomized only group; SDG/FDG: slow/fast distraction groups, with $1 \mathrm{~mm} / 3 \mathrm{~mm}$ lengthening a day, respectively) were used. Signs of increasing postoperative pain were detected until the $10^{\text {th }}$ postoperative day in OG/SDG/FDG, then they decreased in OG but remained higher in SDG/FDG until the distraction finished, suggesting that the pain response is based mainly on surgical trauma until the $10^{\text {th }}$ day, while the lengthening extended its duration and increased its intensity. The only morphological change observed in the DRGs was the presence of large vacuoles in some large neurons of OG/SDG/FDG. Cell size analysis of the S1 DRGs showed no cell loss in any of the three groups; a significant increase in the number of SP-positive large DRG cells in the OG; and a significant decrease in the number of SP-immunoreactive small DRG neurons in the SDG/FDG. Faster and larger distraction resulted in more severe signs of pain sensation, and further reduced the number of SP-positive small cells, compared to slow distraction.

\section{Key words}

Limb-lengthening • Substance P • DRG • Neuropathic pain • Postoperative pain • Rabbit

\section{Corresponding author}

Z. Puskár, Szentágothai János Laboratory, Department of Anatomy, Histology and Embryology, Semmelweis University, Túzoltó u. 58., 1094-Budapest, Hungary. Fax: +36-1-2155158. E-mail: zpuskar@ana.sote.hu

\section{Introduction}

Congenital anomalies and acquired limb length discrepancies cause several physical and mental problems in children suffering from these deformities. Graded limb-lengthening by callus distraction (callotasis) is a surgical procedure widely used to correct tubular bone deformities. Although the functional improvement in children and changes of their life quality are dramatic after the surgery, "its cost in terms of pain" may be high (Young et al. 1994). While postoperative pain following other orthopedic surgical procedures decreases rapidly, continued pain throughout the entire lengthening process, followed by a decreased pain level after the distraction process, is observed in patients undergoing limblengthening (Young et al. 1994). 
Nerve injury is one of the most serious complications of limb-lengthening (Galardi et al. 1990, Nogueira et al. 2003, Velazquez et al. 1993) leading to nerve palsy and chronic neuropathic pain (Antoci et al. 2006, Green 1991, Young et al. 1994). The severe pain is one of the most common causes of interruption of the lengthening process. In this case the fixator has to be removed and the total regeneration of the bone lasting for several months must be waited for. Then further operations are necessary to replace the fixator and to remove it again when the planned extremity length is achieved.

Clinical studies have reported nerve injuries in $0.7-30.0 \%$ of the patients undergoing limb-lengthening procedures. Better understanding of the background of pain associated with limb-lengthening may result in more effective treatments which could save the children from many unnecessary operations and the risk of anesthesia. Although the limb-lengthening techniques attract wide attention because of the improvements provided (93\% increase in bone segment length), only a few studies have been carried out focusing on the effects of the lengthening process on the peripheral and central nervous system.

Peripheral nerve injury generates behavioral signs of persistent pain, and initiates a cascade of events resulting in changes in peptide expression in dorsal root ganglion (DRG) cells and in the spinal dorsal horn. The tachykinin peptide SP is localized in small DRG cells which convey information from peripheral nociceptors (Kellstein et al. 1990, Lawson et al. 1997). SP is released from the primary afferents into the spinal dorsal horn following intense peripheral stimulation (Duggan et al. 1988, 1995, Marvizon et al. 1997) and interacts with neurons expressing neurokinin-1 (NK1) receptor (Brown et al. 1995, Littlewood et al. 1995, Liu et al. 1994, Mantyh et al. 1995). It has been shown that SP is required to generate moderate to intense pain (Cao et al. 1998) and is also responsible for adaptive response to stress (De Felipe et al. 1998). The great majority of spinal lamina I projection neurons express NK1-receptor (Marshall et al. 1996, Todd et al. 2000) and it has been demonstrated that NK1-receptor-expressing cells in superficial dorsal horn are essential for central sensitization, and for establishing and maintaining inflammatory and neuropathic pain states (Khasabov et al. 2002, Mantyh and Hunt 2004, Mantyh et al. 1997, Nichols et al. 1999).

In this study, we developed a clinically relevant model of tibial lengthening in rabbits to detect and quantify the signs of postoperative pain during limblengthening and to study the morphological changes and alteration of SP expression in the DRG.

\section{Methods}

\section{Animals}

The experimental procedures were carried out on New Zealand white rabbits of either sex, weighting 2.5$3.0 \mathrm{~kg}$. All animal experiments were performed in accordance with European Communities Council Directive of 24 November 1986 (86/609/ECC) and were approved by the Committee on Animal Experiments, Semmelweis University, Budapest, Hungary. All efforts were made to minimize the number of animals used and their suffering.

\section{Limb-lengthening model}

Insertion of an external skeletal fixator and osteotomy was performed under deep ketaminemedetomidine general anesthesia $(25 \mathrm{mg} / \mathrm{kg}$ and $0.5 \mathrm{mg} / \mathrm{kg}$ i.m., respectively) in 15 rabbits. The skin was incised on the medial aspect of the hindlimb and the tibia was exposed. An Orthofix-M 101 minifixator with four self-drilling cortical screws intended for metacarpal lengthening in humans was applied and a transverse tibial osteotomy was performed. Care was taken to avoid damaging nerves, muscles and other soft tissues. The cut ends of the tibia were compressed to support callus formation until the $7^{\text {th }}$ postoperative day. The 15 rabbits undergoing the surgical procedure were divided into three groups ( $\mathrm{n}=5$ for each group): in the osteotomized group (OG) osteotomy was not followed by lengthening; in the slow and fast distraction groups (SDG and FDG) osteotomy was followed by distraction initiated at a rate of $1 \mathrm{~mm} /$ day done once a day (for 14 days) and three times a day (for 8 days), respectively, until the bone had reached $120 \%$ and $130 \%$ of its original length (Fig. 1). A further 5 naïve rabbits, which did not undergo any surgical procedure were used as controls. After 3-4 days following the end of the distraction period the animals were sacrificed.

During the experimental procedures, the rabbits were kept in separate standard cages $\left(0.5 \mathrm{~m}^{2} /\right.$ animal $)$ with food and water available ad libitum. The environment was maintained at $22 \pm 2{ }^{\circ} \mathrm{C}$ (60\% humidity) with a $12 \mathrm{~h}$ light-dark cycle. 


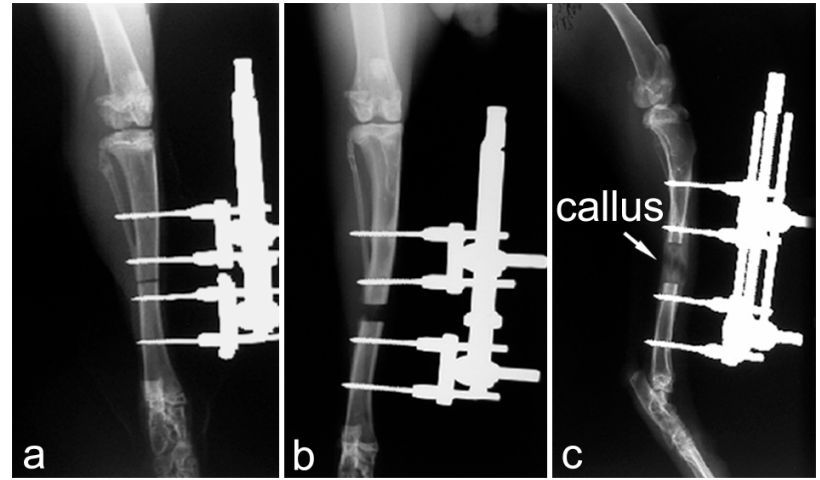

Fig. 1. Postoperative radiographs of the rabbit tibia in standard dorsoplantar and mediolateral projections. Images taken a) immediately after the operation, b) at the $10^{\text {th }}$ postoperative day, and c) at the end of the lengthening demonstrate the positions of the pins, the lengthening and the callus formation, respectively.

\section{$X$-ray analysis}

Three postoperative radiographs (the first taken immediately after the operation, the second at the $10^{\text {th }}$ postoperative day and third at the end of the lengthening period) were made in standard dorsoplantar and mediolateral projections $(50 \mathrm{kV}, 8.0 \mathrm{mAs})$. The positions of the pins were checked on the first radiogram. The callus formation and the lengthening were analyzed on the second and third X-ray picture respectively (Fig. 1).

\section{Autopsy}

Since nerve damage could occur intraoperatively due to physical injury by equipment, or in the distraction phase as a result of nerve impingement on a pin or wire, or entrapment at certain predisposed locations, the proximal tibiofibular junctions were examined immediately after perfusion fixation. The peroneal nerve was exposed at the level of the stifle and was followed to the mid part of the tibia. The position of the pins was examined, and search was made for signs of nerve entrapment.

\section{Behavioral study}

The measurements of the effects of the osteotomy as well as the lengthening processes were carried out from the $7^{\text {th }}$ until the $18^{\text {th }}$ (FDG) or $24^{\text {th }}(\mathrm{SDG})$ days after the osteotomy by an Incapacitance Tester (SG1 3QD, Churchill Electronic Services, Ltd) capable of measuring the load on hindlimbs in grams. The incapacitance was defined as the difference between the loads exerted by hindlimbs expressed as a percentage of the total load exerted.
The statistical comparisons of the data were performed by one way ANOVA followed by TukeyKramer Multiple Comparisons Test.

\section{Immunocytochemistry}

All the rabbits used in the study were perfused with a fixative consisting of $4 \%$ (para)formaldehyde in $0.1 \mathrm{M}$ phosphate buffer (PB), $\mathrm{pH}$ adjusted to 7.4. First sacral (S1) ganglia were removed and postfixed overnight. Longitudinal $50 \mu \mathrm{m}$ sections were cut with a Vibratome and kept in serial order, treated in $50 \%$ ethanol to enhance antibody penetration and then incubated for $72 \mathrm{~h}$ in rat monoclonal SP antibody (AbD Serotec-Oxford Biotechnology; 1:200), and for $24 \mathrm{~h}$ in donkey anti-rat IgG conjugated to Alexa-594 (InvitrogenMolecular Probes, Budapest, Hungary; 1:500). Both the primary and secondary antibodies were diluted in phosphate buffered saline with $0.3 \%$ Triton X-100. Finally, sections were treated for $30 \mathrm{~min}$ with the NeuroTrace blue fluorescent Nissl stain (InvitrogenMolecular Probes; 1:200), then rinsed in PB, mounted in Vectashield (Vector Laboratories) and scanned on a Nikon Eclipse E800 microscope attached to a Bio-Rad Radiance 2100 Rainbow confocal laser scanning system.

\section{Analysis}

Longitudinal sections of S1 DRGs were selected for cell size analysis by using every third section of each series. In each of these sections, overlapping fields of approximately $296 \times 296 \mu \mathrm{m}^{2}$ covering the whole ganglion cross-section were scanned with a $40 \mathrm{x}$ lens using laser beams of $405 \mathrm{~nm}$ and $543 \mathrm{~nm}$ in $\lambda$-mode to reveal fluorescent Nissl staining and SP immunoreactivity. For each field, 20 optical sections were acquired at a zseparation of $1 \mu \mathrm{m}$ in the middle of the full section thickness to avoid double counting of cells in different sections.

Neurolucida for Confocal 4.34 software (MicroBrightField, Williston, VT, USA) was used to measure the long (LA) and short (SA) axes of the neuron cross-sections. Only cells that had a visible nucleolus within the $20 \mu \mathrm{m}$ thick stack of optical sections were analysed. This method led to the counting of $1369 \pm 389$ neurons per DRG. Since the shape of the majority of neurons in transverse sections through the ganglion was elliptical, the cross-sectional areas were calculated using the formula: area $=\pi(\mathrm{LA})(\mathrm{SA}) / 4$ (Farel and Mcllwain 2000, Weissner et al. 2006).

Due to the fact that the fluorescent Nissl method 
and the SP immunoreaction resulted a slightly different pattern of staining within individual neurons, the LA and SA of a selected neuron differed slightly, depending on whether SP immunoreactivity or Nissl staining was used to make the measurements. To standardize the measurement, all SP-immunoreactive cells were measured both ways and a correction factor was calculated and applied for those cells which were not SPpositive: area $=\pi(1.07 \mathrm{LA})(1.07 \mathrm{SA}) / 4$. For statistical analysis, proportions of the SP-positive neurons in different groups were compared by z-test ("Difference between two proportions-test"). The level of significance used was $\mathrm{p}<0.05$. Statistical analysis was done using SAS statistical software package (SAS/STAT, Software Release 9.1.3., SAS Institute Inc., NC, USA).

\section{Results}

\section{Animals}

All rabbits recovered well after surgery. During the study there was no observable prostration, lack of appetite and body weight loss of the rabbits. No signs of infection or inflammation were observed in any of the animals. Furthermore, neither malposition of the pins nor malunion was found during the distraction period. In addition, neither impingement nor entrapment of the nerve was observed in any rabbits.

\section{Behavioral study}

Measures of weight-bearing on the two hindlimbs in each group (naïve; OG: osteotomized only group; SDG/FDG: slow/fast distraction groups, with $1 \mathrm{~mm} / 3 \mathrm{~mm}$ lengthening a day, respectively) are shown in Figure 2. All operated animals preferentially bore weight on the unoperated hindlimb.

The differences in the incapacitance of the naïve and the operated groups were significant throughout the investigation period. The incapacitance gradually increased till the $10^{\text {th }}$ postoperative day $\left(3^{\text {rd }}\right.$ day of elongation) in all 3 operated groups and started to decrease slightly in the OG from that time point. Statistically significant differences in the incapacitance between the OG and lengthened groups were recorded between the $15^{\text {th }}$ and $21^{\text {st }}$ postoperative days and disappeared again in the SDG as distraction was terminated but a moderate decrease of incapacitance was observable also in the FDG. Application of the $3 \mathrm{~mm} /$ day elongation produced an increased incapacitance during the study.

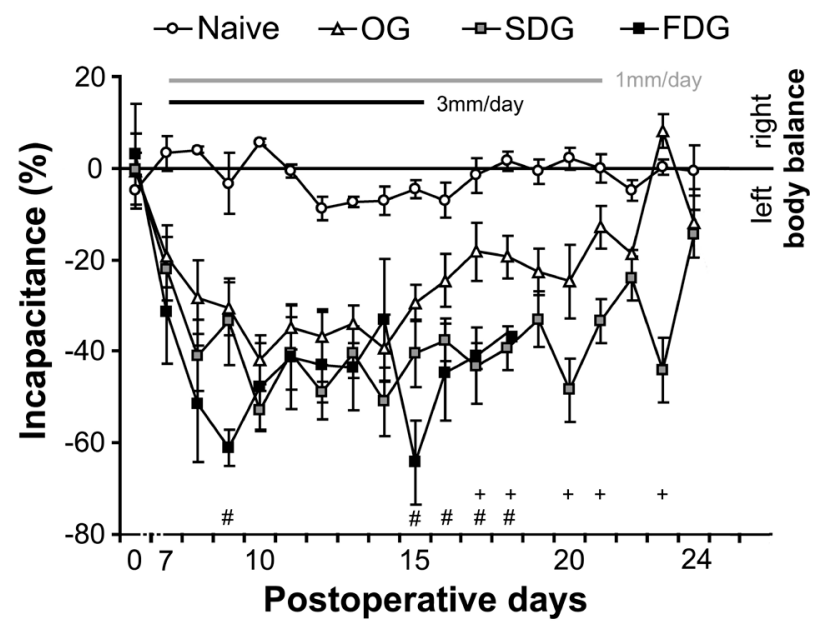

Fig. 2. Postoperative pain measurements in rabbits. Time-course of changes in incapacitance calculated from the measurements of weight bearing capacity of the hindlimbs in naïve, osteotomized $(\mathrm{OG})$, slow (SDG) and fast (FDG) distraction animals. Data indicate mean \pm SEM. Statistical analysis: one-way ANOVA, Tukey-Kramer post hoc test, ${ }^{+} p<0.05$ OG vs. SDG, ${ }^{\#} p<0.05$ OG vs. FDG

\section{SP expression}

The pattern of immunostaining for SP (Fig. 3) and the proportion of SP-positive neurons in naïve rabbit DRGs were very similar to those reported in rats (Weissner et al. 2006). SP was expressed in $26.6 \pm 2.9 \%$ of the total number of counted cells in S1 DRGs. Detailed size analysis of DRG neurons in rabbits has not been carried out previously. The cross-sectional area of 6707 cells in the 5 DRGs was calculated using the measured longest and smallest diameter of the individual neurons according to the description of (Weissner et al. 2006). The size distribution was skewed, and appeared bimodal when plotted on log scale (Fig. 4), as reported for rat (Lawson 1979, Weissner et al. 2006). The two peaks of the histogram represented two overlapping cell populations by size. The SP-positive neurons seemed to be associated with the first peak. Fitting the two size distributions by maximum likelihood placed the intersection at $992.3 \mu^{2}$ in naïve rabbits, which divided the neurons into two groups: small cells $\left(\leq 992 \mu \mathrm{m}^{2}\right)$ and the large cells $\left(\geq 992 \mu \mathrm{m}^{2}\right)$ in the ganglion. In naïve rabbits $19.7 \pm 3.5 \%$ and $6.9 \pm 2.8 \%$ of the SP-immunoreactive DRG neurons belonged to the small and large cell groups, respectively.

In OG animals, $28.0 \pm 1.0 \%$ of the neurons were SP-positive which did not differ significantly from the naive group $(p=0.2903)$. In the lengthened groups, although the total number of cells did not change, the proportion that were SP-immunoreactive decreased 


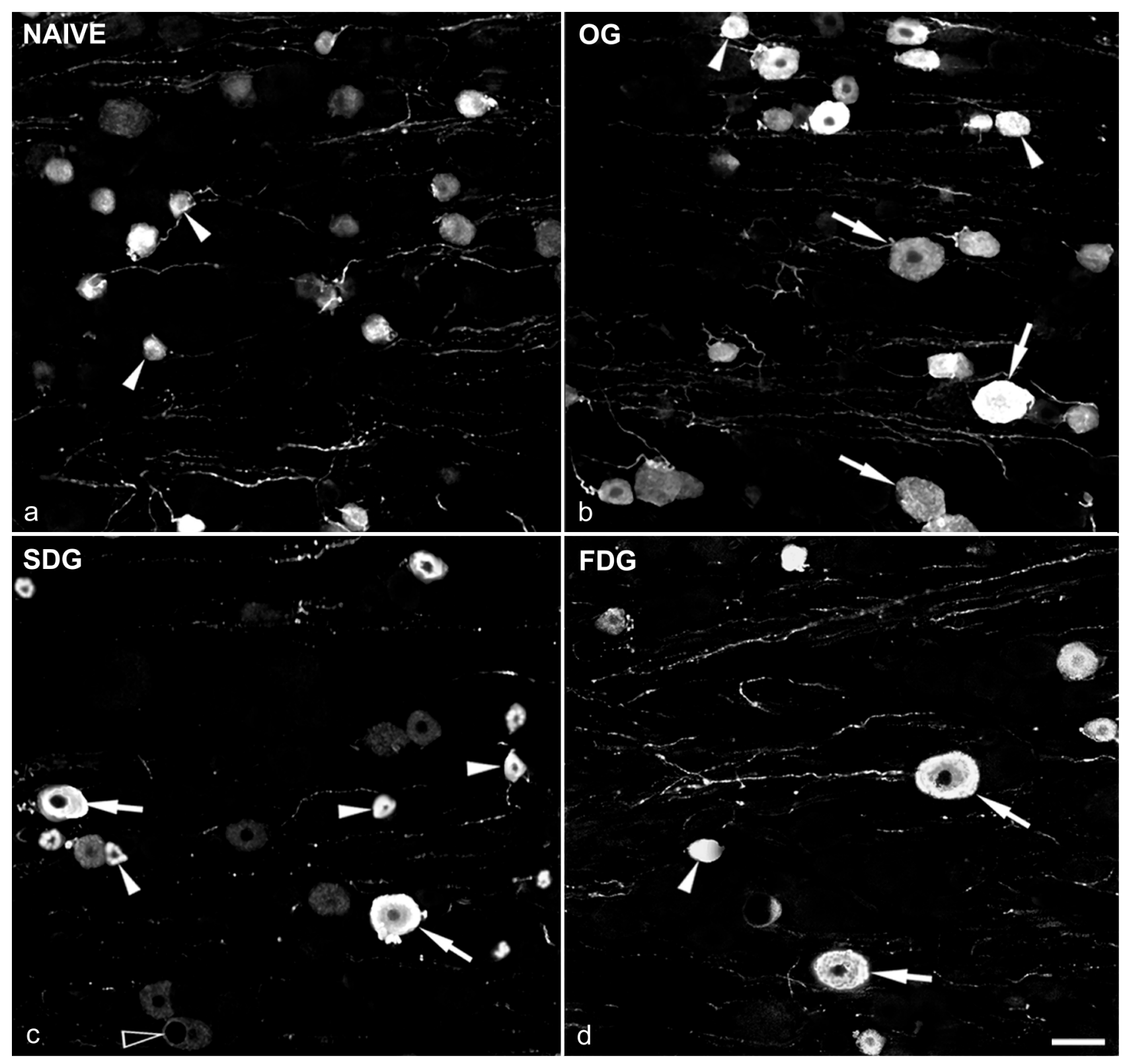

Fig. 3. Confocal images showing SP immunoreactivity in $S 1$ dorsal root ganglia. DRGs were obtained from a) naïve, b) osteotomized $(\mathrm{OG})$, c) slow (SDG), and d) fast (FDG) distraction groups. Arrowheads: SP-positive small neurons, arrows: SP stained large DRG cells. Each picture shows a projection of 5 optical sections at $1 \mu \mathrm{m}$ z-separation. Scale bar: $50 \mu \mathrm{m}$

significantly $(18.0 \pm 1.8 \%$ and $15.9 \pm 2.5 \%$ in SDG and FDG, respectively) compared to both the naïve (naïve vs. SDG: $p<0.01$; naïve vs. FDG: $p<0.01)$ and the OG (OG vs. SDG: $p<0.01$; OG vs. FDG: $p<0.01)$. Furthermore, the ratio of the SP-positive small and large cells also altered in the $\mathrm{OG}$ and the lengthened groups. The proportion of SP-positive small cells (SDG: $11.5 \pm 0.9 \%$, FDG: $7.9 \pm 1.9 \%$ ) decreased significantly (control vs. SDG: $\mathrm{p}<0.01$, control vs. FDG: $\mathrm{p}<0.01$ ), while the proportion of stained large cells (SDG: $6.7 \pm 1.5 \%$, FDG: $7.9 \pm 2.4 \%$ ) did not change significantly (control vs. SDG: $\mathrm{p}=0.81$; control vs. FDG: $p=0.21$ ) in the lengthened groups. In addition, the faster distraction yielded a further significant decrease in the number of SP immunostained small cells in the FDG compared to the SDG (SDG vs. FDG: $\mathrm{p}<0.01)$. Interestingly, in the $\mathrm{OG}$, the number of the SP-immunoreactive small neurons (17.1 $\pm 2.7 \%)$ decreased only slightly $(\mathrm{p}=0.11)$, whereas the number of the stained large cells $(11.1 \pm 3.5 \%)$ increased significantly $(\mathrm{p}<0.01)$ compared to the control group (small neurons: $19.7 \pm 3.5 \%$, large neurons: $6.9 \pm 2.8 \%$ ). Proportions of SP-containing cells in different groups are summarized on Figure 5. 

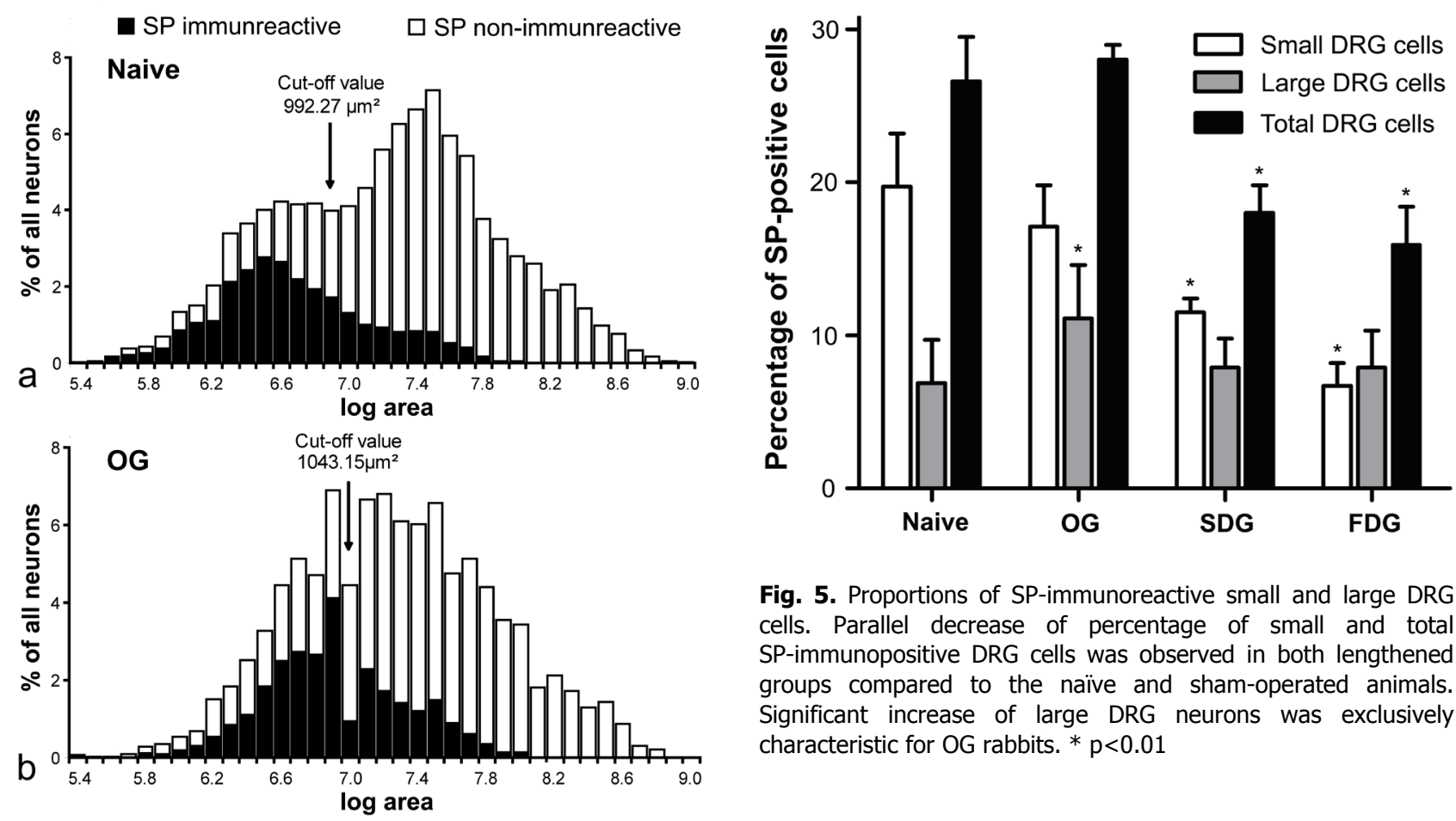

Fig. 5. Proportions of SP-immunoreactive small and large DRG cells. Parallel decrease of percentage of small and total SP-immunopositive DRG cells was observed in both lengthened groups compared to the naïve and sham-operated animals. Significant increase of large DRG neurons was exclusively characteristic for $\mathrm{OG}$ rabbits. $* \mathrm{p}<0.01$
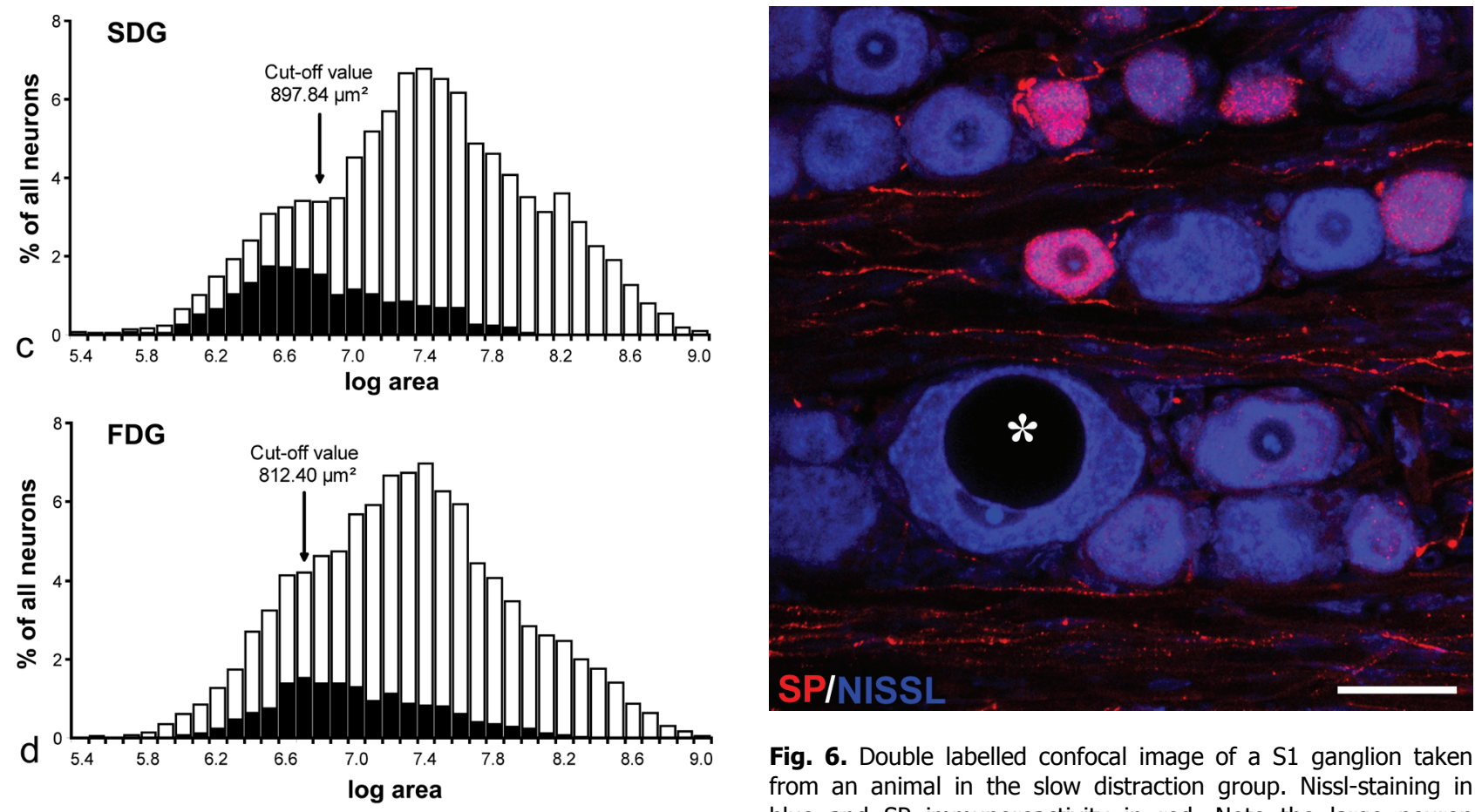

Fig. 4. Size distribution of $S 1$ dorsal root ganglion neurons in naïve (a), osteotomized (b; OG), slow (c; SDG) and fast (d; FDG) distraction animals. All measured neurons (27 376 cells of 20 S1 DRGs) were separated by the presence (shaded bars) or absence (open bars) of SP and were binned by area in 0.1 natural log increments as it was demonstrated in rats by Weissner et al. (2006).

\section{Morphological changes in DRG cells}

At the light microscopic level, the location and distribution of the supporting (satellite) cells did not show any abnormality either in osteotomized and the

Fig. 6. Double labelled confocal image of a S1 ganglion taken from an animal in the slow distraction group. Nissl-staining in blue and SP immunoreactivity in red. Note the large neuron (asterisk) with eccentric nucleus and huge vacuole in the cytoplasm. Image was obtained from a stack of 3 optical sections, z-spacing: $1 \mu \mathrm{m}$. Scalebar: $50 \mu \mathrm{m}$

lengthened animals following the surgery. The general morphological appearance of the small ganglion cells was normal in these groups. The only obvious difference was found in some large cells. The nucleus of certain large neurons became eccentric and huge vacuoles appeared in the cytoplasm (Fig. 6). Among the counted neurons, 3-4 vacuolated large cells in OG, 13- 
15 in SDG and 13-17 in FDG were found per DRG.

Vacuolated large DRG neurons expressing SP were not found in any operated groups.

\section{Discussion}

\section{Behavioral study}

Animal models of neuropathic pain have been established in rats and mice, however, the limblengthening procedure would not be easy to carry out in these species because of the size of their limbs. Since precise insertion of the fixator was essential to avoid surgical complications, a longer bone was required and, hence, the rabbit tibia was selected. However, quantifying signs of pain in rabbits is complex. The most commonly used behavioral tests (e.g. hot-plate test, von Frey filaments) developed for rodents are difficult to carry out because rabbit hindpaw is hairy. Consequently, these tests have not been standardized on rabbits, and no baseline data is available.

In this study we measured the load on hindlimbs in grams then applied the definition of the incapacitance. This measurement clearly showed the time course and the extent of the changes in the weight bearing capacity of the operated limbs. The decreased weight bearing capacity suggested tenderness of the involved limbs. Since no signs of infection or inflammation were detected during the study, it suggested that the increased tenderness of the operated legs resulted from the surgical and lengthening procedures.

\section{Model of limb-lengthening}

The pain measurements in our study demonstrated an increasing postoperative pain response till the $10^{\text {th }}$ postoperative day both in the $\mathrm{OG}$ and the lengthened groups, which then decreased gradually in the OG animals, but lasted for a further 2 weeks in the lengthened groups. These results suggest that the pain response was based mainly on the surgical trauma until the $15^{\text {th }}$ day. Since the autopsy did not show any signs of nerve impingement or entrapment, the long-lasting pain response which started to decrease when the lengthening process completed in the lengthened groups was presumably maintained by the nerve stretch during the distraction period. Furthermore the more rapid lengthening (by $3 \mathrm{~mm} /$ day) of the affected limb led to more severe signs of pain. The time course and pattern of postoperative pain described in this study are in very good agreement with clinical reports taken from humans following limb lengthening (Young et al. 1994).

\section{Cell size distribution}

Detailed size analysis of S1 DRG neurons was carried out in rabbits as demonstrated in rats by Weissner et al. (2006). Figure 3 shows that the "large" cell population in the rabbit S1 DRG is much bigger (relative to the "small" population) than is the case for the rat L5 ganglion. Furthermore the SP staining is limited to small neurons in normal rats, whereas SP is also expressed in a small population of large DRG cells in naïve rabbits.

\section{Vacuolar changes in the DRGs}

Vacuolar changes in large DRG neurons in both the $O G$ and the lengthened groups, described in this work, were also reported previously in rats after unilateral transection of sciatic nerve (Groves et al. 1997). It was demonstrated that these neurons were viable and existed for a long period of time following axotomy. Administration of neurotrophin-3 markedly reduced the incidence of the vacuolated cells in the DRGs in this type of injury. It was concluded that vacuolization of certain type of cells represented a specific type of pathological response to nerve injury (Groves et al. 1997).

\section{SP expression and pain}

It is well known that peripheral nerve injury not only generates behavioral signs of persistent pain but results in changes in peptide expression in dorsal root ganglion (DRG) cells and in the spinal dorsal horn. Calcitonin gene-related peptide (CGRP) and SP are down-regulated while other peptides such as vasoactive intestinal polypeptide (VIP) and galanin (GAL) are upregulated, while neuropeptide Y (NPY) is expressed de novo (Baranowski et al. 1993, Henken et al. 1990, Hokfelt et al. 1994, Jessell et al. 1979, Nielsch et al. 1987, Noguchi et al. 1993, 1990a,b, 1989, Villar et al. 1989, Wakisaka et al. 1992). Since the antibodies from different hosts and sources against CGRP, VIP, GAL and NPY, routinely used in our laboratory, did not worked on rabbit tissue, the only change we could study was the SP expression.

Although it has been demonstrated that SP is down regulated in small but up regulated in large DRG cells in different models of nerve injury (Baranowski et al. 1993, Bisby and Keen 1986, Honore et al. 2000, Kobayashi et al. 2004, Ma and Bisby 1998, Swamydas et al. 2004, Tessler et al. 1985, Villar et al. 1989, Weissner 
et al. 2006), the functional meaning of these changes is still unknown.

It has been reported that alterations in peptide expression appear 3 days after nerve injury and last much longer than 2 weeks (Kajander and Xu 1995, Malmberg and Basbaum 1998, Munglani et al. 1996, Sommer and Myers 1995). This suggests that if osteotomy and the lengthening processes affected the SP expression, this should have been detected at the time point at which animals were sacrificed in our experiments (18 days in FDG and 24 days in OG and SDG following osteotomy).

It has been proposed that in a distal tibial fracture model, SP signaling contributes to the vascular and nociceptive changes (pain and allodynia) (Guo et al. 2004). In our limb-lengthening model, although all animals were osteotomized in the operated groups, the changes in SP expression were completely different in the OG and in the lengthened groups, suggesting that the osteotomy induced postoperative pain might not be related to the alteration of SP expression. Possible explanations for the discrepancy between the findings in these two studies include species differences (rat vs. rabbit), and the fact that cast immobilization was used by Guo et al. (2004). A further difference between the two studies was that distal limb edema was observed in the fracture model, but was not seen in our study.

Mechanical allodynia (pain in response to nonnoxious mechanical stimuli) is one of the most characteristic features of chronic pain, including inflammatory, neuropathic and postoperative pain syndromes. Allodynia appears in patients undergoing limb-lengthening (Pap et al., unpublished observation). Several lines of evidence suggested that de novo expression of SP in A $\beta$ cutaneous afferents (Noguchi et al. 1994, Weissner et al. 2006) may contribute to allodynia after certain types of nerve injuries (Weissner et al. 2006). However, other studies failed to detect SP release in the spinal cord following electrical stimulation of $A \beta$ afferents belonging to the chronically transected sciatic nerve (Allen et al. 1999, Malcangio et al. 2000). Furthermore, Hughes et al. (2007) did not observe SP-immunoreactivity in the central terminals of $\mathrm{A} \beta$ afferents in the dorsal horn either in chronic constriction injury or in spinal nerve ligation models. One of the most notable results of our study is that although osteotomy was carried out, vacuolization was seen in the large DRG neurons and the pain pattern was very similar till the $10^{\text {th }}$ day in all 3 operated groups, significant increase in the number of SP positive large cells appeared only in the OG. This data does not support the contribution of $A \beta$ afferents to the pain behavior in our model.

Kozlova et al. (1986) have pointed out a significant growth-promoting effect of SP for sympathetic ganglia and spinal cord culture and highlighted the functional significance of SP in nerve tissue development and regeneration. Since the osteotomy was not followed by further intervention in the OG in our study, the decreasing signs of pain from the $15^{\text {th }}$ day suggested an ongoing regeneration in the nervous system. Accordingly, de novo expression of SP in large sensory neurons may reflect the regeneration of the injured cells in the DRG or the nervous system. This finding is in a good agreement with the previous suggestion, that after nerve injury the primary role of the sensory neurons changes from neurotransmission to cell survival and regeneration (Hokfelt et al. 1994).

Previous studies have demonstrated that the anatomical and behavioral changes correlate in different models of nerve injury (Cameron et al. 1997, Malmberg and Basbaum 1998). An important finding of our study is that a significant decrease in the number of SPimmunoreactive small DRG neurons was detected solely in the lengthened groups. The increased and maintained pain response was in good correlation with the decreased SP expression in the small DRG cells in the lengthened groups. Faster and larger distraction resulted in a more severe pain response and lowered further the number of SP positive small cells compared to slow distraction. These observations demonstrate that nerve stretch injury shares common features with other nerve injury models. At the same time, in contrast to other models, this model clearly shows the correlation between the rate of the injury and the changes in the SP expression and pain responses.

\section{Future perspective}

Since the gradual lengthening itself does not cause permanent injury, the model used in this work is suitable not only for studying the pathological changes but also the regeneration processes which may contribute to preventing or ameliorating the postoperative pain. As the pain pattern described in this model is in good agreement with human studies, the effects of new analgesics could also be tested.

\section{Conflict of Interest}

There is no conflict of interest. 


\section{Acknowledgements}

We thank Prof. A. J. Todd and Dr. I. Nagy for helpful discussion and advice, Prof. E. Dinya for the statistics and Ms E. Oszwald and Ms E. Lukácsi for the excellent technical assistance. This work was supported by the Hungarian Scientific research Fund (OTKA-PD 101248).

\section{References}

ALLEN BJ, LI J, MENNING PM, ROGERS SD, GHILARDI J, MANTYH PW, SIMONE DA: Primary afferent fibers that contribute to increased substance $\mathrm{P}$ receptor internalization in the spinal cord after injury. J Neurophysiol 81: 1379-1390, 1999.

ANTOCI V, ONO CM, ANTOCI V Jr, RANEY EM: Bone lengthening in children: how to predict the complications rate and complexity? J Pediatr Orthop 26: 634-640, 2006.

BARANOWSKI AP, PRIESTLEY JV, MCMAHON S: Substance P in cutaneous primary sensory neurons a comparison of models of nerve injury that allow varying degrees of regeneration. Neuroscience 55: 1025 1036, 1993.

BISBY MA, KEEN P: Regeneration of primary afferent neurons containing substance P-like immunoreactivity. Brain Res 365: 85-95, 1986.

BROWN JL, LIU H, MAGGIO JE, VIGNA SR, MANTYH PW, BASBAUM AI: Morphological characterization of substance $\mathrm{P}$ receptor-immunoreactive neurons in the rat spinal cord and trigeminal nucleus caudalis. $J$ Comp Neurol 356: 327-344, 1995.

CAMERON AA, CLIFFER KD, DOUGHERTY PM, GARRISON CJ, WILLIS WD, CARLTON SM: Time course of degenerative and regenerative changes in the dorsal horn in a rat model of peripheral neuropathy. $J$ Comp Neurol 379: 428-442, 1997.

CAO YQ, MANTYH PW, CARLSON EJ, GILLESPIE AM, EPSTEIN CJ, BASBAUM AI: Primary afferent tachykinins are required to experience moderate to intense pain. Nature 392: 390-394, 1998.

DE FELIPE C, HERRERO JF, O'BRIEN JA, PALMER JA, DOYLE CA, SMITH AJ, LAIRD JM, BELMONTE C, CERVERO F, HUNT SP: Altered nociception, analgesia and aggression in mice lacking the receptor for substance P. Nature 392: 394-397, 1998.

DUGGAN AW, HENDRY IA, MORTON CR, HUTCHISON WD, ZHAO ZQ: Cutaneous stimuli releasing immunoreactive substance $P$ in the dorsal horn of the cat. Brain Res 451: 261-273, 1988.

DUGGAN AW, RILEY RC, MARK MA, MACMILLAN SJ, SCHAIBLE HG: Afferent volley patterns and the spinal release of immunoreactive substance $\mathrm{P}$ in the dorsal horn of the anaesthetized spinal cat. Neuroscience 65: 849$858,1995$.

FAREL PB, MCILWAIN DL: Neuron addition and enlargement in juvenile and adult animals. Brain Res Bull 53: $537-$ $546,2000$.

GALARDI G, COMI G, LOZZA L, MARCHETTINI P, NOVARINA M, FACCHINI R, PARONZINI A: Peripheral nerve damage during limb lengthening. Neurophysiology in five cases of bilateral tibial lengthening. $J$ Bone Joint Surg Br 72: 121-124, 1990.

GREEN SA: Postoperative management during limb lengthening. Orthop Clin North Am 22: 723-734, 1991.

GROVES M, GIOMETTO B, SCARAVILLI F: Axotomy-induced vacuolation of primary sensory neurons and effect of administered neurotrophic factors: a morphometric, immunocytochemical and ultrastructural study. Primary Sensory Neuron 2: 111-127, 1997.

GUO TZ, OFFLEY SC, BOYD EA, JACOBS CR, KINGERY WS: Substance P signaling contributes to the vascular and nociceptive abnormalities observed in a tibial fracture rat model of complex regional pain syndrome type I. Pain 108: 95-107, 2004.

HENKEN DB, BATTISTI WP, CHESSELET MF, MURRAY M, TESSLER A: Expression of beta-preprotachykinin mRNA and tachykinins in rat dorsal root ganglion cells following peripheral or central axotomy. Neuroscience 39: 733-742, 1990.

HOKFELT T, ZHANG X, WIESENFELD-HALLIN Z: Messenger plasticity in primary sensory neurons following axotomy and its functional implications. Trends Neurosci 17: 22-30, 1994. 
HONORE P, ROGERS SD, SCHWEI MJ, SALAK-JOHNSON JL, LUGER NM, SABINO MC, CLOHISY DR, MANTYH PW: Murine models of inflammatory, neuropathic and cancer pain each generates a unique set of neurochemical changes in the spinal cord and sensory neurons. Neuroscience 98: 585-598, 2000.

HUGHES DI, SCOTT DT, RIDDELL JS, TODD AJ: Upregulation of substance P in low-threshold myelinated afferents is not required for tactile allodynia in the chronic constriction injury and spinal nerve ligation models. J Neurosci 27: 2035-2044, 2007.

JESSELL T, TSUNOO A, KANAZAWA I, OTSUKA M: Substance P: depletion in the dorsal horn of rat spinal cord after section of the peripheral processes of primary sensory neurons. Brain Res 168: 247-259, 1979.

KAJANDER KC, XU J: Quantitative evaluation of calcitonin gene-related peptide and substance P levels in rat spinal cord following peripheral nerve injury. Neurosci Lett 186: 184-188, 1995.

KELLSTEIN DE, PRICE DD, HAYES RL, MAYER DJ: Evidence that substance P selectively modulates C-fiberevoked discharges of dorsal horn nociceptive neurons. Brain Res 526: 291-298, 1990.

KHASABOV SG, ROGERS SD, GHILARDI JR, PETERS CM, MANTYH PW, SIMONE DA: Spinal neurons that possess the substance $P$ receptor are required for the development of central sensitization. $J$ Neurosci 22: 90869098, 2002.

KOBAYASHI S, YOSHIZAWA H, YAMADA S: Pathology of lumbar nerve root compression. Part 2: Morphological and immunohistochemical changes of dorsal root ganglion. J Orthop Res 22: 180-188, 2004.

KOZLOVA MV, IL'INSKII OB, KALENCHUK VU, KONDRIKOVA ES: Activating effect of substance P on nerve tissue in culture. (in Russian) Neirofiziologiia 18: 610-615, 1986.

LAWSON SN: The postnatal development of large light and small dark neurons in mouse dorsal root ganglia: a statistical analysis of cell numbers and size. J Neurocytol 8: 275-294, 1979.

LAWSON SN, CREPPS BA, PERL ER: Relationship of substance P to afferent characteristics of dorsal root ganglion neurones in guinea-pig. J Physiol 505: 177-191, 1997.

LITTLEWOOD NK, TODD AJ, SPIKE RC, WATT C, SHEHAB SA: The types of neuron in spinal dorsal horn which possess neurokinin-1 receptors. Neuroscience 66: 597-608, 1995.

LIU H, BROWN JL, JASMIN L, MAGGIO JE, VIGNA SR, MANTYH PW, BASBAUM AI: Synaptic relationship between substance $\mathrm{P}$ and the substance $\mathrm{P}$ receptor: light and electron microscopic characterization of the mismatch between neuropeptides and their receptors. Proc Natl Acad Sci U S A 91: 1009-1013, 1994.

MA W, BISBY MA: Increase of preprotachykinin mRNA and substance P immunoreactivity in spared dorsal root ganglion neurons following partial sciatic nerve injury. Eur J Neurosci 10: 2388-2399, 1998.

MALCANGIO M, RAMER MS, JONES MG, MCMAHON SB: Abnormal substance P release from the spinal cord following injury to primary sensory neurons. Eur J Neurosci 12: 397-399, 2000.

MALMBERG AB, BASBAUM AI: Partial sciatic nerve injury in the mouse as a model of neuropathic pain: behavioral and neuroanatomical correlates. Pain 76: 215-222, 1998.

MANTYH PW, HUNT SP: Setting the tone: superficial dorsal horn projection neurons regulate pain sensitivity. Trends Neurosci 27: 582-584, 2004.

MANTYH PW, DEMASTER E, MALHOTRA A, GHILARDI JR, ROGERS SD, MANTYH CR, LIU H, BASBAUM AI, VIGNA SR, MAGGIO JE, ET AL.: Receptor endocytosis and dendrite reshaping in spinal neurons after somatosensory stimulation. Science 268: 1629-1632, 1995.

MANTYH PW, ROGERS SD, HONORE P, ALLEN BJ, GHILARDI JR, LI J, DAUGHTERS RS, LAPPI DA, WILEY RG, SIMONE DA: Inhibition of hyperalgesia by ablation of lamina I spinal neurons expressing the substance $P$ receptor. Science 278: 275-279, 1997.

MARSHALL GE, SHEHAB SA, SPIKE RC, TODD AJ: Neurokinin-1 receptors on lumbar spinothalamic neurons in the rat. Neuroscience 72: 255-263, 1996.

MARVIZON JC, MARTINEZ V, GRADY EF, BUNNETT NW, MAYER EA: Neurokinin 1 receptor internalization in spinal cord slices induced by dorsal root stimulation is mediated by NMDA receptors. $J$ Neurosci 17: 81298136, 1997.

MUNGLANI R, HARRISON SM, SMITH GD, BOUNTRA C, BIRCH PJ, ELLIOT PJ, HUNT SP: Neuropeptide changes persist in spinal cord despite resolving hyperalgesia in a rat model of mononeuropathy. Brain Res 743: 102-108, 1996. 
NICHOLS ML, ALLEN BJ, ROGERS SD, GHILARDI JR, HONORE P, LUGER NM, FINKE MP, LI J, LAPPI DA, SIMONE DA, MANTYH PW: Transmission of chronic nociception by spinal neurons expressing the substance P receptor. Science 286: 1558-1561, 1999.

NIELSCH U, BISBY MA, KEEN P: Effect of cutting or crushing the rat sciatic nerve on synthesis of substance P by isolated L5 dorsal root ganglia. Neuropeptides 10: 137-145, 1987.

NOGUCHI K, SENBA E, MORITA Y, SATO M, TOHYAMA M: Prepro-VIP and preprotachykinin mRNAs in the rat dorsal root ganglion cells following peripheral axotomy. Brain Res Mol Brain Res 6: 327-330, 1989.

NOGUCHI K, SENBA E, MORITA Y, SATO M, TOHYAMA M: Alpha-CGRP and beta-CGRP mRNAs are differentially regulated in the rat spinal cord and dorsal root ganglion. Brain Res Mol Brain Res 7: 299-304, 1990a.

NOGUCHI K, SENBA E, MORITA Y, SATO M, TOHYAMA M: Co-expression of alpha-CGRP and beta-CGRP mRNAs in the rat dorsal root ganglion cells. Neurosci Lett 108: 1-5, 1990 b.

NOGUCHI K, DE LEON M, NAHIN RL, SENBA E, RUDA MA: Quantification of axotomy-induced alteration of neuropeptide mRNAs in dorsal root ganglion neurons with special reference to neuropeptide Y mRNA and the effects of neonatal capsaicin treatment. J Neurosci Res 35: 54-66, 1993.

NOGUCHI K, DUBNER R, DE LEON M, SENBA E, RUDA MA: Axotomy induces preprotachykinin gene expression in a subpopulation of dorsal root ganglion neurons. J Neurosci Res 37: 596-603, 1994.

NOGUEIRA MP, PALEY D, BHAVE A, HERBERT A, NOCENTE C, HERZENBERG JE: Nerve lesions associated with limb-lengthening. J Bone Joint Surg Am 85: 1502-1510, 2003.

SOMMER C, MYERS RR: Neurotransmitters in the spinal cord dorsal horn in a model of painful neuropathy and in nerve crush. Acta Neuropathol 90: 478-485, 1995.

SWAMYDAS M, SKOFF AM, ADLER JE: Partial sciatic nerve transection causes redistribution of pain-related peptides and lowers withdrawal threshold. Exp Neurol 188: 444-451, 2004.

TESSLER A, HIMES BT, KRIEGER NR, MURRAY M, GOLDBERGER ME: Sciatic nerve transection produces death of dorsal root ganglion cells and reversible loss of substance P in spinal cord. Brain Res 332: 209-218, 1985.

TODD AJ, MCGILL MM, SHEHAB SA: Neurokinin 1 receptor expression by neurons in laminae I, III and IV of the rat spinal dorsal horn that project to the brainstem. Eur J Neurosci 12: 689-700, 2000.

VELAZQUEZ RJ, BELL DF, ARMSTRONG PF, BABYN P, TIBSHIRANI R: Complications of use of the Ilizarov technique in the correction of limb deformities in children. J Bone Joint Surg Am 75: 1148-1156, 1993.

VILLAR MJ, CORTES R, THEODORSSON E, WIESENFELD-HALLIN Z, SCHALLING M, FAHRENKRUG J, EMSON PC, HOKFELT T: Neuropeptide expression in rat dorsal root ganglion cells and spinal cord after peripheral nerve injury with special reference to galanin. Neuroscience 33: 587-604, 1989.

WAKISAKA S, KAJANDER KC, BENNETT GJ: Effects of peripheral nerve injuries and tissue inflammation on the levels of neuropeptide Y-like immunoreactivity in rat primary afferent neurons. Brain Res 598: 349-352, 1992.

WEISSNER W, WINTERSON BJ, STUART-TILLEY A, DEVOR M, BOVE GM: Time course of substance P expression in dorsal root ganglia following complete spinal nerve transection. J Comp Neurol 497: 78-87, 2006.

YOUNG N, BELL DF, ANTHONY A: Pediatric pain patterns during Ilizarov treatment of limb length discrepancy and angular deformity. J Pediatr Orthop 14: 352-357, 1994. 